ISSN: 2638-5279

Volume 3, Issue 1, 2020, PP: 14-21

\title{
Aerosol Particulates, SARS-CoV-2, and the Broader Potential for Global Devastation
}

\author{
J. Marvin Herndon, Ph.D. ${ }^{1}$, Mark Whiteside, M.D., M.P.H ${ }^{2}$ \\ ${ }^{1}$ Transdyne Corporation, 11044 Red Rock Drive, San Diego, CA 92131 USA. \\ ${ }^{2}$ Medical Director, Florida Department of Health in Monroe County, 1100 Simonton Street, Key West, USA. \\ *Corresponding Author: J. Marvin Herndon, Ph.D., Transdyne Corporation, 11044 Red Rock Drive, San Diego, CA \\ 92131 USA.
}

Abstract

Particulate pollution has multiple, well-known, serious adverse consequences on human and environmental health. Airborne transmission has been identified as the dominant route in the global spread of COVID-19. Several lines of evidence now point to particulate pollution as a possible co-factor in the COVID-19 Pandemic, specifically, as a potential means of viral transport, and as a role in exacerbating susceptibility and mortality, and diminishing immune response to the SARS-CoV-2 virus. The association of particulate pollution with the COVID-19 Pandemic is a wake-up call to humanity that foreshadows even greater global devastation through undisclosed particulate pollution. Even in the midst of this Pandemic, we submit, the medical and public health community and others must demand a full and open accounting of all that transpired with respect to the causality of and response to the SARS-CoV-2 virus, including deliberate aerosol particulate pollution.

Keywords: COVID-19; Particulate pollution; ENMOD; Aerosol particulates; Particulate jet-emplacement; Environmental modification.

\section{INTRODUCTION}

The COVID-19 Pandemic, due to the SARS-CoV-2 virus, is a wake-up call to humanity, reminding us of our vulnerability and the necessity for global integrity with regard to human and environmental health. Liquid particulates, especially exhaled bioaerosol droplets, are frequently discussed in connection with personto-person viral transmission [1-3]. The recent studies reviewed here, however, highlight the importance of solid particulate pollution as a potential means of its viral transport, and its role in exacerbating susceptibility and mortality, and diminishing immune response. Particulate pollution solids portend even greater global devastation.

\section{METHODS}

Review articles are written in different ways to achieve different results $[4,5]$. The approach we use in this review is to gather seemingly unrelated facts scattered through the literature, which when arranged logically, reveal causal relationships and lead to new understanding [6]. Detailed multi-discipline literature searches were conducted to reveal medical connections and implications between the SARS-Co-V pandemic and particulate aerosol pollution.

\section{Discussion}

\section{SARS-CoV-2 - Particulate Association}

In 1989 Hammond et al. [7] postulated that atmospheric dispersion and intercontinental transport of aerosolized influenza virus may contribute to the "spread, persistence, and ubiquity of the disease, the explosiveness of epidemics, and the prompt regionwide occurrence of outbreaks." In 2006, Tellier [8] reviewed the evidence that infectious influenza virus is transported by aerosol particles. In 2015, Bao et al. [9] investigated the three dimensional microstructure of aerosol particles, and noted that coal fly ash, a major pollutant, contains many pores which may be possible virus carriers. They suggest that transmission of pandemic influenzas by this mechanism potentially explains long-distance transmission. As both are airborne contagion, those implications for influenza $[10,11]$ also apply to the SARS-CoV-2 virus $[12,13]$. 
The observed correlation between the high levels of lethality of SARS-CoV-2 and atmospheric pollution in Northern Italy led Conticini et al. [14] to suggest that atmospheric pollution might be a co-factor for COVID-19. A similar conclusion was reached for a different viral illness by Su et al. [15] who found that air pollutants can increase the risk of influenza-like illness. Particulate pollutants also degrade immune defense mechanisms $[16,17]$.

Setti et al. [18] discovered the first preliminary evidence indicating the existence of SARS-CoV-2 on collected samples of outdoor, airborne, particulate matter (PM) from an industrial site in the highlethality [19] Province of Bergamo in Northern Italy. A large-scale epidemiological investigation in the United States found that an increase of 1 (one) $\mu \mathrm{g} / \mathrm{m}^{3}$ in $\mathrm{PM}_{2.5}$ is associated (at a 95\% confidence interval) with a $15 \%$ increase in the SARS-CoV-2 death rate [20].

\section{Nature of Particulate Pollution}

Particulate pollution is usually thought to arise from natural sources, e.g. windblown sand and forest-fire ash, or from anthropogenic sources, e.g. machine abrasion, fossil fuel emissions, and coal combustion. There is a more pernicious source of particulate pollution that is being deliberately and covertly jetemplaced into the troposphere on a near-daily, near global basis, and which evidence indicates is mainly coal fly ash, the abundant waste product of coal burning [21-23]. This particulate pollution is typically evident as white (occasionally black) trails across the sky, that spread out, briefly resembling cirrus clouds, before becoming a white haze, as shown in Figure 1.

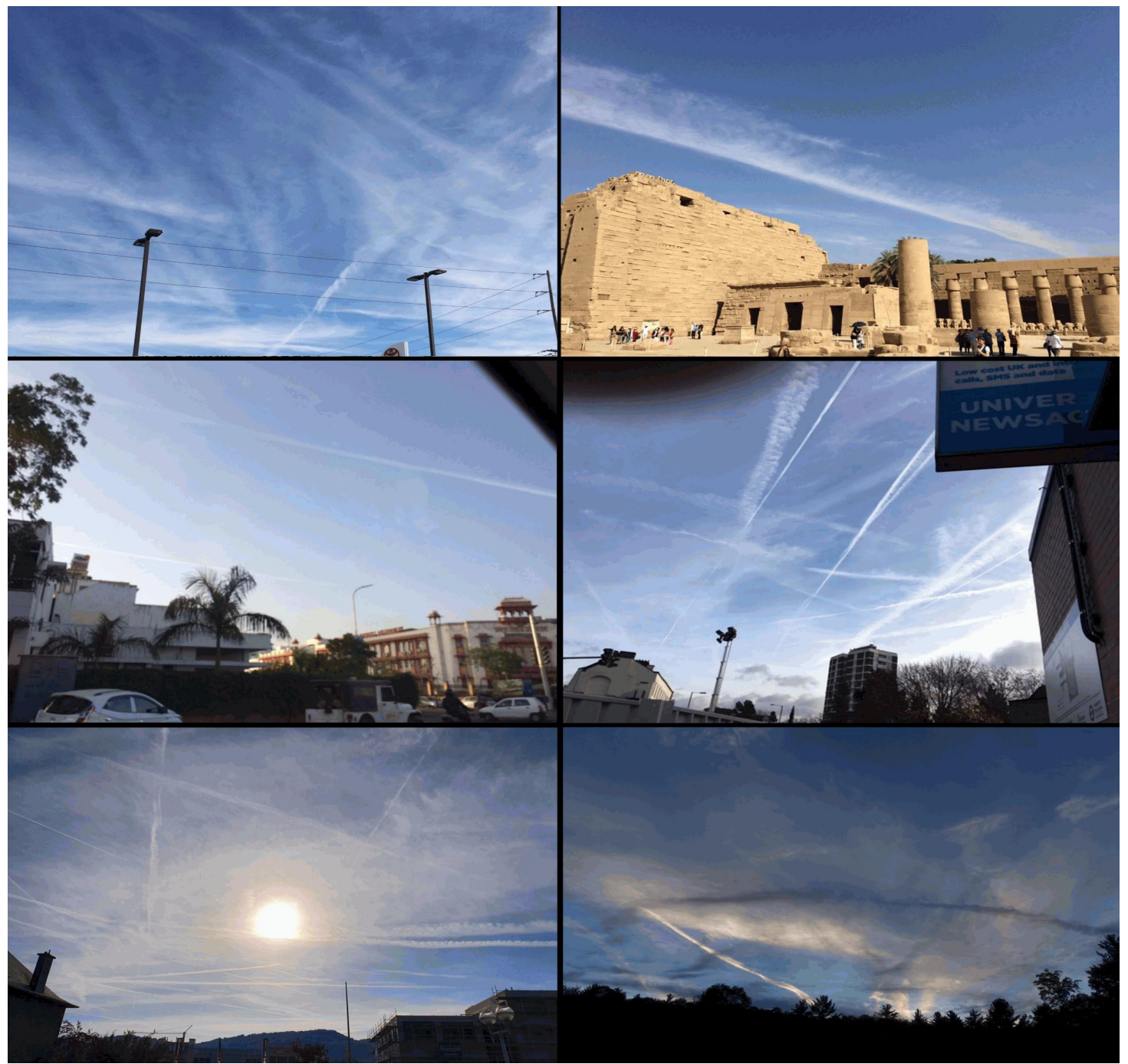

Figure1. Deliberate jet-emplaced particulate trails, clockwise from top left San Diego, California, USA; Karnack, Egypt; London, England; Danby, Vermont, USA; Luxemborg; Jaipur, India. 
The jet-dispersal of particulates into the troposphere has been undertaken with ever-increasing frequency, intensity, and geographical range for more than a decade without regard for public health. Moreover, concerted efforts are made [24,25] to deceive the public into believing that the aerial particulates are harmless ice-crystal contrails from aircraft engine exhaust-moisture. That contrail-deception is contrary to scientific evidence based upon radiometric measurements [22] and observations [23], including the lower-right photograph of Figure 1 that shows black trails that cannot be composed of ice-crystals.

Even commercial airlines are involved in the deliberate atmospheric pollution [23]. Aside from the health risks arising from the aerosolized particulate-matter itself, lack of high-level security at airports affords 'bad actors' a potential opportunity the engage in biological warfare by contaminating the commercial airlines' aerial feed-stock.

Activities that pose risks to human health should never be cloaked in secrecy; the human and environmental health risks should be revealed, not misrepresented, including their legal basis. The supposedly legal basis of the undisclosed, deliberate particulate pollution was a mystery [26] until we cracked the code [27]. As shown in Figure 2, numerous nations signed on to a Trojan horse treaty [28] entitled "Convention on the Prohibition of Military or Any Other Hostile Use of Environmental Modification Techniques" [hereafter ENMOD]. Trojan horse is an appropriate descriptor as ENMOD does not do what its title indicates, but instead it sanctions the use of "environmental modification techniques" for "peaceful purposes" and, moreover, obligates each signatory "State Party" to cooperate in unspecified environmental "improvement" operations by an unspecified international organization for unspecified purposes [27]. As used in that treaty [28] "the term 'environmental modification techniques'refers to any technique for changing - through the deliberate manipulation of natural processes - the dynamics, composition or structure of the Earth, including its biota, lithosphere, hydrosphere and atmosphere, or of outer space."

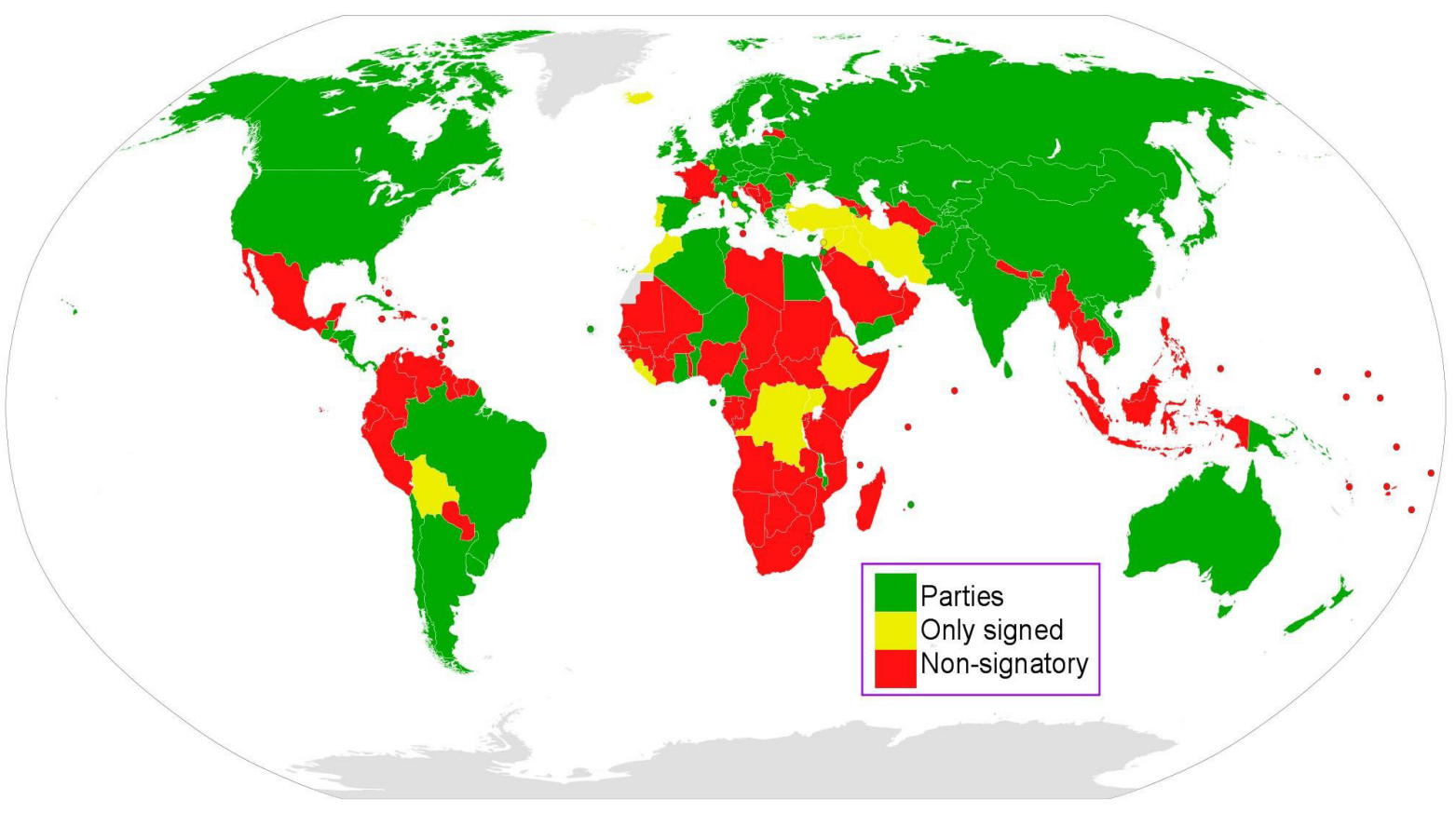

Figure2. ENMOD status of sovereign nations as of January 3, 2018. From [27].

Particulate matter jet-sprayed into the troposphere reduces atmospheric convective heat-loss from the surface, producing local and/or global warming [29$31]$ and potentially melting polar ice [32,33]. Moreover, the jet-sprayed particulates disrupt stable weather patterns and habitats [23,34-37], producing droughts, floods, and crop failures [26,38], decimating bat [39], bird [40], and insect [41] populations, worsening wildfires [23], killing forests [42], facilitating harmful aquatic algae [43], enabling pestilence [44], and destroying the ozone layer [45]. In short, global environmental warfare [46]. 
Air pollution is the leading environmental cause of morbidityand mortality worldwide [47,48]. Particulate matter with combustion-morphology has been found in the brains of persons with dementia [49]. Numerous reactive iron magnetic particulates were found in the hearts of persons from highly polluted areas [50]. Particulate air pollution is a significant contributor to heart, stroke, and neurodegenerative disease [49-52] and is a risk factor for increased premenopausal breast cancer [53], decreased male fertility [54], cognitive decline [55-58] and for Alzheimer's Dementia later in life [55]. Particulate air pollution is also a risk factor for children having cognitive defects $[57,58]$ and for Autism Spectrum Disorder in children $[59,60]$.

Particulate air pollution is a major contributor to respiratory diseases, including lung cancer [61], COPD [62], respiratory infections [63], and asthma [64]. $\mathrm{PM}_{2.5}$ injury mechanisms include free radical peroxidation, oxidative stress, imbalanced intracellular calcium homeostasis, and induction of inflammatory processes [65]. Pollution particles can deposit throughout the respiratory track and, if sufficiently small, can enter the bloodstream [ref] and deposit in the brain [49] or heart [50]. $\mathrm{PM}_{2.5}$ exposure is associated with lower respiratory tract infection in children and adults [66]. It is not surprising, therefore, that particulate air pollution exposure predisposes individuals to increased lethality from SARS-CoV-2 [20].

Previous experimental and observational studies on interhuman transmission have shown a significant role of aerosols in the transmission of respiratory viruses including influenza, SARS-Co-V-1, and Middle East Respiratory Virus IMERS). Airborne transmission was recently established as the dominant route of spread of COVID-19 [67]. Inhalation of virus-laden fine particles deep into the nasopharynx, tracheobronchial area, and lungs would certainly increase the chance of multisystem infection by COVID-19. Investigations of adsorption and survival of COVID-19 on the surface of particulate matter and mechanisms of virus-particle entry into the body are needed to better understand the role of air pollution in COVID-19 transmission [68]. It is likely that long-term (and cumulative) exposure to air pollutants is one of the most important contributors to the spread and severity of COVID-19 on a world-wide basis [69].

\section{Conclusions}

The COVID-19 Pandemic should give humanity serious pause for reflection. The SARS-CoV-2 virus might return in a more aggressive form; other pandemics will inevitably follow. Through arrogance and blind obedience, sovereign nations have opted to participate in modifying our planetary environment and have done so without question, without public disclosure, and without informed consent $[22,23]$. Life is possible because of the multitude of complex interactions by and between biota and their respective environments. Environmental modification cannot be peaceful, but is extremely hostile - de facto environmental warfare. The suffering and global devastation caused by the SARS-CoV-2 virus on a short time-frame prefigures the slow planetary demise that will inevitably result from continued application of the Trojan horse ENMOD treaty [28] "through the deliberate manipulation of natural processes - the dynamics, composition or structure of the Earth, including its biota, lithosphere, hydrosphere and atmosphere, or of outer space."

In the aftermath of the COVID-19 Pandemic, we submit, the medical and public health community and others should demand a full and open accounting of all that transpired with the causality of and response to the SARS-CoV-2 virus; steps should be taken to prevent its ever happening again. The steps to be taken should include ending forever the deliberate aerial particulate pollution and the revocation of the deceptive ENMOD treaty [28] by each of the signatory nations.

\section{Abbreviations}

COVID-19: coronavirus disease 2019; SARS-CoV-2: severe acute respiratory syndrome coronavirus. ENMOD: Convention on the Prohibition of Military or Any Other Hostile Use of Environmental Modification Techniques.

\section{REFERENCES}

[1] Sattar SA, Ijaz MK, Gerba CP. Spread of viral infections by aerosols. Critical Reviews in Environmental Science and Technology. 1987;17(2):89-131.

[2] Ijaz M, Brunner A, Sattar S, Nair RC, JohnsonLussenburg C. Survival characteristics of airborne human coronavirus 229E. Journal of General Virology. 1985;66(12):2743-8.

[3] Edwards DA, Man JC, Brand P, Katstra JP, Sommerer K, Stone HA, et al. Inhaling to mitigate exhaled bioaerosols. Proceedings of the National Academy of Sciences. 2004;101(50):17383-8. 
[4] Garrido ID, López LR, Seda JD, Aparcero LB, Chacartegui IM. Types, structure, and function of scientific articles. Archivos espanoles de urologia. 2002;55(8):890-3.

[5] Eady AM, Wilczynski NL, Haynes RB, Team H. PsycINFO search strategies identified methodologically sound therapy studies and review articles for use by clinicians and researchers. Journal of clinical epidemiology. 2008;61(1):34-40.

[6] Herndon JM. Inseparability of science history and discovery. Hist Geo Space Sci. 2010;1:25-41.

[7] Hammond G, Raddatz R, Gelskey D. Impact of atmospheric dispersion and transport of viral aerosols on the epidemiology of influenza. Reviews of infectious diseases. 1989;11(3):494-7.

[8] Tellier R. Review of aerosol transmission of influenza A virus. Emerging infectious diseases. 2006;12(11):1657.

[9] Bao L, Zhang G, Lei Q, Li Y, Li X, Hwu Y, et al. Microstructure of atmospheric particles revealed by TXM and a new mode of influenza virus transmission. Nuclear Instruments and Methods in Physics Research Section B: Beam Interactions with Materials and Atoms. 2015;359:167-72.

[10] Knight V. Viruses as agents of airborne contagion. Annals of the New York Academy of Sciences. 1980;353(1):147-56.

[11] Couch R, Kasel J, Glezen W, Cate T, Six H, Taber $\mathrm{L}$, et al. Influenza: its control in persons and populations. Journal of Infectious Diseases. 1986;153(3):431-40.

[12] Chen X, Shang Y, Yao S, Liu R, Liu H. Perioperative care provider's considerations in managing patients with the COVID-19 infections. Transl Perioper Pain Med. 2020.

[13] Cascella M, Rajnik M, Cuomo A, Dulebohn SC, Di Napoli R. Features, Evaluation and Treatment Coronavirus (COVID-19). StatPearls [Internet]: StatPearls Publishing; 2020.

[14] Conticini E, Frediani B, Caro D. Can atmospheric pollution be considered a co-factor in extremely high level of SARS-CoV-2 lethality in Northern Italy? Environmental Pollution. 2020:114465.
[15] Su W, Wu X, Geng X, Zhao X, Liu Q, Liu T. The short-term effects of air pollutants on influenzalike illness in Jinan, China. BMC public health. 2019;19(1):1-12.

[16] Wu J, Zhu K, Luo X, Han Y, Zhang B, Wang Z, et al. PM2. 5 promotes replication of VSV by ubiquitination degradation of phospho-IRF3 in A549 cells. Toxicology in Vitro. 2020;62:104698.

[17] Ma J-H, Song S-H, Guo M, Zhou J, Liu F, Peng L, et al. Long-term exposure to PM2. 5 lowers influenza virus resistance via down-regulating pulmonary macrophage Kdm6a and mediates histones modification in IL- 6 and IFN- $\beta$ promoter regions. Biochemical and biophysical research communications. 2017;493(2):1122-8.

[18] Setti L, Passarini F, De Gennaro G, Baribieri P, Perrone MG, Borelli M, et al. SARS-Cov-2 RNA Found on Particulate Matter of Bergamo in Northern Italy: First Preliminary Evidence. medRxiv. 2020:2020.04.15.20065995.

[19] Veiceschi P, Brembilla C, Bernucci C. Effects of COVID-19 outbreak in Northern Italy. Perspectives from Bergamo Neurosurgery Department. World Neurosurgery. 2020.

[20] Wu X, Nethery RC, Sabath BM, Braun D, Dominici F. Exposure to air pollution and COVID19 mortality in the United States. medRxiv. 2020:2020.04.05.20054502.

[21] Herndon JM, Whiteside M. Further evidence of coal fly ash utilization in tropospheric geoengineering: Implications on human and environmental health. J Geog Environ Earth Sci Intn. 2017;9(1):1-8.

[22] Herndon JM, Hoisington RD, Whiteside M. Chemtrails are not contrails: Radiometric evidence. J Geog Environ Earth Sci Intn. 2020;24(2):22-9.

[23] Herndon JM, Whiteside M. California wildfires: Role of undisclosed atmospheric manipulation and geoengineering. J Geog Environ Earth Sci Intn. 2018;17(3):1-18.

[24] Shearer C, West M, Caldeira K, Davis SJ. Quantifying expert consensus against the existence of a secret large-scale atmospheric spraying program. Environ Res Lett. 2016;11(8):p. 084011. 
Aerosol Particulates, SARS-CoV-2, and the Broader Potential for Global Devastation

[25] Tingley D, Wagner G. Solar geoengineering and the chemtrails conspiracy on social media. Palgrave Communications. 2017;3(1):12.

[26] Herndon JM, Whiteside M, Baldwin I. Fifty Years after "How to Wreck the Environment": Anthropogenic Extinction of Life on Earth. J Geog Environ Earth Sci Intn. 2018;16(3):1-15.

[27] Herndon JM, Whiteside M, Baldwin I. The ENMOD treaty and the sanctioned assault on agriculture and human and environmental health. Agrotechnology. 2020;9(191):1-9.

[28] http://www.un-documents.net/enmod.htm

[29] Herndon JM. Air pollution, not greenhouse gases: The principal cause of global warming. J Geog Environ Earth Sci Intn. 2018;17(2):1-8.

[30] Herndon JM. Role of atmospheric convection in global warming. J Geog Environ Earth Sci Intn. 2019;19(4):1-8.

[31] Herndon JM, Whiteside M. Further evidence that particulate pollution is the principal cause of global warming: Humanitarian considerations. Journal of Geography, Environment and Earth Science International. 2019;21(1):1-11.

[32] Herndon JM. An indication of intentional efforts to cause global warming and glacier melting. J Geography Environ Earth Sci Int. 2017;9(1):1-11.

[33] Herndon JM. Evidence of variable Earth-heat production, global non-anthropogenic climate change, and geoengineered global warming and polar melting. J Geog Environ Earth Sci Intn. 2017;10(1):16.

[34] Vogel E, Donat MG, Alexander LV, Meinshausen M, Ray DK, Karoly D, et al. The effects of climate extremes on global agricultural yields. Environmental Research Letters. 2019;14(5):054010.

[35] Scheelbeek PF, Bird FA, Tuomisto HL, Green R, Harris FB, Joy EJ, et al. Effect of environmental changes on vegetable and legume yields and nutritional quality. Proceedings of the National Academy of Sciences. 2018;115(26):6804-9.

[36] Tigchelaar M, Battisti DS, Naylor RL, Ray DK. Future warming increases probability of globally synchronized maize production shocks.
Proceedings of the National Academy of Sciences. 2018;115(26):6644-9.

[37] https://www.nytimes.com/2019/04/30/ dining/farming-climate-change.html

[38] Herndon JM. Adverse agricultural consequences of weather modification. AGRIVITA Journal of agricultural science. 2016;38(3):213-21.

[39] Herndon JM, Whiteside M. Unacknowledged potential factors in catastrophic bat die-off arising from coal fly ash geoengineering. Asian Journal of Biology. 2019;8(4):1-13.

[40] Whiteside M, Herndon JM. Aerosolized coal fly ash: A previously unrecognized primary factor in the catastrophic global demise of bird populations and species. Asian J Biol. 2018;6(4):1-13.

[41] Whiteside M, Herndon JM. Previously unacknowledged potential factors in catastrophic bee and insect die-off arising from coal fly ash geoengineering Asian J Biol. 2018;6(4):1-13.

[42] Herndon JM, Williams DD, Whiteside M. Previously unrecognized primary factors in the demise of endangered torrey pines: A microcosm of global forest die-offs. J Geog Environ Earth Sci Intn 2018;16(4):1-14.

[43] Whiteside M, Herndon JM. Role of aerosolized coal fly ash in the global plankton imbalance: Case of Florida's toxic algae crisi. Asian Journal of Biology. 2019;8(2):1-24.

[44] El Husseini MM. Weather Engineering and its Undesirable Side Effects on the Environment, Natural Resources, Agriculture and Human. Acta Scientific Agriculture. 2019;3.7.

[45] Herndon JM, Hoisington RD, Whiteside M. Deadly ultraviolet UV-C and UV-B penetration to Earth's surface: Human and environmental health implications. J Geog Environ Earth Sci Intn. 2018;14(2):1-11.

[46] Herndon JM, Whiteside M. Global Environmental Warfare. Advances in Social Sciences Research Journal. 2020;7(4):411-22.

[47] Landrigan PJ, Fuller R, Acosta NJ, Adeyi $\mathrm{O}$, Arnold $\mathrm{R}$, Baldé $\mathrm{AB}$, et al. The Lancet Commission on pollution and health. The lancet. 2018;391(10119):462-512. 
[48] Friedrich M. Air Pollution Is Greatest Environmental Threat to Health. JAMA. 2018;319(11):1085.

[49] Maher BA, Ahmed IA, Karloukovski V, MacLaren DA, Foulds PG, Allsop D, et al. Magnetite pollution nanoparticles in the human brain. Proc Nat Acad Sci. 2016;113(39):10797-801.

[50] Calderón-Garcidueñas L, González-Maciel A, Mukherjee PS, Reynoso-Robles R, Pérez-Guillé B, Gayosso-Chávez C, et al. Combustion-and frictionderived magnetic air pollution nanoparticles in human hearts. Environmental Research. 2019:108567.

[51] Jeremy W. Air pollution and brain health: an emerging issue. Lancet. 2017;390:1345-422.

[52] Whiteside M, Herndon JM. Aerosolized coal fly ash: Risk factor for neurodegenerative disease. Journal of Advances in Medicine and Medical Research. 2018;25(10):1-11.

[53] Villeneuve PJ, Goldberg MS, Crouse DL, To T, Weichenthal SA, Wall C, et al. Residential exposure to fine particulate matter air pollution and incident breast cancer in a cohort of Canadian women. Environmental Epidemiology. 2018;2(3):e021.

[54] Pires A, de Melo EN, Mauad T, Saldiva PHN, Bueno HMdS. Pre- and postnatal exposure to ambient levels of urban particulate matter (PM2.5) affects mice spermatogenesis. Inhalation Toxicology: International Forum for Respiratory Research: DOI: 103109/089583782011563508. 2011;23(4).

[55] Kilian J, Kitazawa M. The emerging risk of exposure to air pollution on cognitive decline and Alzheimer's disease-evidence from epidemiological and animal studies. Biomedical journal. 2018.

[56] Weuve J, Puett RC, Schwartz J, Yanosky JD, Laden F, Grodstein F. Exposure to particulate air pollution and cognitive decline in older women. Archives of internal medicine. 2012;172(3):219-27.

[57] Calderón-Garcidueñas L, Azzarelli B, Acuna H, Garcia R, Gambling TM, Osnaya N, et al. Air pollution and brain damage. Toxicologic Pathology. 2002;30(3):373-89.
[58] Calderon-Garciduenas L, Franko-Lira M, MoraTiscareno A, Medina-Cortina H, Torres-Jardon R, al. e. Early Alzheimer'd and Parkinson's diese pathology in urban children: Friend verses foe response - it's time to face the evidence. BioMed Research International. 2013;32:650-8.

[59] Becerra TA, Wilhelm M, Olsen J, Cockburn M, Ritz B. Ambient air pollution and autism in Los Angeles county, California. Environmental health perspectives. 2012;121(3):380-6.

[60] Talbott EO, Arena VC, Rager JR, Clougherty JE, Michanowicz DR, Sharma RK, et al. Fine particulate matter and the risk of autism spectrum disorder. Environmental Research. 2015;140:414-20.

[61] Whiteside M, Herndon JM. Coal fly ash aerosol: Risk factor for lung cancer. Journal of Advances in Medicine and Medical Research. 2018;25(4):1-10.

[62] Whiteside M, Herndon JM. Aerosolized coal fly ash: Risk factor for COPD and respiratory disease. Journal of Advances in Medicine and Medical Research. 2018;26(7):1-13.

[63] MacIntyre EA, Gehring U, Mölter A, Fuertes E, Klümper C, Krämer U, et al. Air pollution and respiratory infections during early childhood: an analysis of 10 European birth cohorts within the ESCAPE Project. Environmental health perspectives. 2013;122(1):107-13.

[64] Ambient air pollution - a global assessment of exposure and burden of disease. Geneva: World Health Organization (WHO) 2016.

[65] Xing Y-F, Xu Y-H, Shi M-H, Lian Y-X. The impact of PM2. 5 on the human respiratory system. Journal of thoracic disease. 2016;8(1):E69.

[66] Horne BD, Joy EA, Hofmann MG, Gesteland PH, Cannon JB, Lefler JS, et al. Short-term elevation of fine particulate matter air pollution and acute lower respiratory infection. American journal of respiratory and critical care medicine. 2018;198(6):759-66.

[67] Zhang R, Li Y, Zhang AL, Wang Y, Molina MJ. Identifying airborne transmission as the dominant route for the spread of COVID-19. Proceedings of the National Academy of Sciences. 2020. 
[68] Qu G, Li X, Hu L, Jiang G. An imperative need for research on the role of environmental factors in transmission of novel coronavirus (COVID-19). Environmental Science and Technology; 2020. p. $3730-2$.
[69] Ogen Y. Assessing nitrogen dioxide (NO2) levels as a contributing factor to the coronavirus (COVID-19) fatality rate. Science of The Total Environment. 2020:138605.

Citation: J. Marvin Herndon, Mark Whiteside. Aerosol Particulates, SARS-CoV-2, and the Broader Potential for Global Devastation. Open Access Journal of Internal Medicine. 2020; 3(1): 14-21.

Copyright: (C) 2020 J. Marvin Herndon, Mark Whiteside. This is an open access article distributed under the Creative Commons Attribution License, which permits unrestricted use, distribution, and reproduction in any medium, provided the original work is properly cited. 